\title{
НАСЛІДКИ ПАНДЕМІї COVID-19 ДЛЯ СОЦІАЛЬНОї РОБОТИ В УКРАЇНI
}

\author{
Бутиліна О. В., к.сои.н., доиент, доиент кафедри соиіології управління та соиіальної роботи, \\ Харківський національний університет імені В. Н. Каразіна м. Харків, Украйна, \\ Свдокимова I. А., к.сои.н., доцент, доцент-в.о. завідувача кафедри соиіологї̈ управління та \\ соиіальної роботи, Харківський національний університет імені В. Н. Каразіна, м. Харків, \\ Украйна,
}

Плахова О. М., к.сои.н., доиент, доиент кафедри соиіології управління та соиіальної роботи, Харківський наиіональний університет імені В. Н. Каразіна м. Харків, Украйна,

DOI: https://doi.org/10.31435/rsglobal_conf/25112020/7259

\begin{abstract}
The article analyzes the consequences of the COVID-19 pandemic for social work in Ukraine. It is emphasized that social work as a professional activity was formed in the period of industrialism in response to the "obvious" risks of society. In modern conditions, social work is under the influence of the pandemic COVID-19, which is the most influential global "implicit" risk, which significantly transforms this area of professional activity. It is noted that the consequences of the COVID-19 pandemic can be analyzed separately for social work clients, social workers, social agencies and the social work institute as a whole. The authors study the consequences of the COVID19 pandemic for state social agencies, their social workers and clients in Ukraine.

The provisions of the theory of immune behavior is used and it is concluded that the pandemic is an important factor in forming of protective models of "immune behavior" for social work clients and social workers and can lead to significant transformation of the institute of social work in Ukrainian society.
\end{abstract}

Keywords: risk, pandemic, social work, risk society, social institution, state social agency, "immune behavior".

Вступ. Виникнення пандемії COVID-19 кардинально змінило майже всі сфери життя, призвело до появи нових норм та практик, загострило соціальну напругу, стимулювало широке застосування інформаційних технологій, посилило проблему самотності, соціальної нерівності тощо . В усіх сферах суспільного життя відбуваються процеси мобілізації усіх наявних ресурсів для того, щоб протистояти новим викликам, виробити заходи компенсування, мінімізації або блокування їх негативного впливу, окреслити форми захисту від них. У цьому контексті соціальна робота як професійна діяльність, що спрямована на попередження і вирішення гострих соціальних проблем, також знаходиться під впливом пандемії. Очевидно, що своєчасне відстеження цих змін $є$ важливим науковим завданням, адже це дозволить краще зрозуміти особливості трансформації соціальної роботи та, можливо, - забезпечити коригування цих змін. У той же час, незважаючи на актуальність, такі дослідження поки що майже відсутні в Україні.

Мета дослідження - здійснити аналіз наслідків пандемії COVID-19 для соціальної роботи в Україні.

Результати дослідження. Професійна соціальна робота виникає в країнах Західної Європи та США на рубежі XIX - XX століття як суспільна відповідь на постійно зростаючу кількість складних життєвих обставин, які унеможливлюють гідне існування людини в суспільстві. Економічні та соціальні відносини в суспільстві в цілому та в межах особистого життєвого простору людини, іiі сім'ї породжували різні за масштабом та мірою впливу джерела ризику. Неврегульованість питань, пов'язаних із найманням на роботу, оплатою праці, втратою працездатності, важкими й шкідливими умовами виробництва, тривалістю робочого часу, відсутністю елементарних форм охорони праці, високим рівнем травматизму, дитячою зайнятістю, породжувала соціальні ризики, високу конфліктність трудових відносин. Держава під тиском вимог трудящих почала реалізовувати функцію соціального захисту шляхом формування правової бази, що регламентує різні сторони трудових відносин. Саме ці умови існування людини наприкінці XIX - початку XX ст. стали рушійною силою для появи різних систем соціального захисту, які реалізовувалися переважно через професійну соціальну роботу. 
Першою європейською країною, яка запровадила соціально-трудове законодавство, була Англія. У 1802 р. з'являється перший фабричний закон, що став найбільш ранньою спробою поліпшення санітарно-гігієнічних умов праці найманих робітників. Закон визначав заходи щодо попередження нещасних випадків на виробництві, обмежував тривалість робочого часу. У 1842 p. затверджують акт, що забороняє підземну нічну роботу дітей і підлітків та вперше встановлює урядову фабричну інспекцію. У Франції та Німеччині правове поле трудових відносин вибудовується в другій половині ХІХ ст. Так, у Франції в період Паризької Комуни (1871р.) приймають декрет, що забороняе нічну роботу в пекарнях, відміняються довільні штрафи й утримання із заробітної плати працівників. У 1898 р. ухвалено закон про виробничий травматизм. Згідно 3 ним роботодавець став відповідати за всі виробничі ризики й виплату компенсації робітникам. У Німеччині в 1871 р. прийнято «Закон про матеріальну відповідальність». Він встановлював відповідальність власників залізничних підприємств за нещасні випадки, які відбулися із працівниками, зайнятими на будівництві й обслуговуванні залізничних колій i складів. У 1883 - 1889 рр. були видані закони про страхування у зв’язку з хворобою, про страхування від нещасного випадку, про страхування через інвалідність і старість [3]. Німеччина стала першою країною у світі, яка запровадила солідарну пенсію для всіх працюючих. Фінансування пенсій здійснювалося за рахунок роботодавців і працівників. Наприкінці XIX ст. законодавчо встановлені правила й норми, що регламентують трудові відносини, з'являються й у інших країнах Європи. Стає нормою, коли весь спектр економічних витрат, пов'язаних із питаннями техніки безпеки, гігієни й медицини праці, компенсації втрати працездатності через нещасні випадки на виробництві й професійні захворювання несе роботодавець. Таким чином, у XIX ст. соціально-трудове законодавство виступило формою соціального захисту працездатного, зайнятого населення від ризиків, що погіршують його соціальне становище.

$\mathrm{У}$ перше десятиліття XX ст. практично всі розвинуті держави проводять активну експансію в соціальну сферу: вибудовують соціальну політику, створюють правову базу, розробляють моделі та системи соціальної підтримки населення. У цей же час відбувається і процес становлення професійної соціальної роботи, яка пройшла шлях від родової, конфесійної, приватної благодійності, професійно-групової та державної підтримки та стала суспільно визнаною професією.

Інтенсивний розвиток капіталізму, що характеризує цей період часу, супроводжувався залученням жінок та дітей у виробництво, посиленою експлуатацією, масовим зубожінням найманих працівників i, як наслідок, ростом революційних виступів населення. Поглиблення рівня соціальної диференціації, відсутність або слабкість державних механізмів соціального захисту сприяло соціальним вибухам, які вразили світ на початку XX ст. Революційні рухи на Заході, революції в Росії, Перша світова війна, «велика депресія» в США змусили владу різних держав розробляти адекватні заходи щодо соціального захисту населення, активно втілювати соціальну політику та соціальну роботу. Відбулося усвідомлення того факту, що ринкові (капіталістичні) відносини нівелюють соціальні та моральні засади людського співіснування. Ринок не забезпечував стабільну зайнятість працездатного населення. Кожен повинен був самостійно піклуватися про себе, що призводило до соціального розшарування та посилювало соціальну напругу. Все розмаїття можливих ризиків сконцентрувалося в одному домінуючому ризику - втраті трудового доходу. Наймані працівники, які не мали приватної власності як економічної основи самодопомоги, втративши також і традиційні психологічні способи підтримки, об'єктивно мали потребу в нових формах соціальної допомоги.

Особливо активно процес становлення соціальної роботи як окремої професійної діяльності проходив у США, де після Громадянської війни (1861- 1865 рр.) гостро постало питання піклування про незаможних, розумово неповноцінних $\mathrm{i}$ засуджених за правопорушення. Ці категорії громадян потрапляли під опіку й захист адміністрацій штатів, однак у них не завжди вистачало ресурсів щоб адекватно реагувати на різні вияви соціальної патології. У громадському секторі почали з'являтися добровольчі організації й агентства, які надавали соціальну допомогу, найбільш відомі з них - Гільдія сеттлментів та Халл-хаус. Перші школи 3 підготовки соціальних працівників з'явились у країнах Західної Європи на початку ХХ ст. - у 1903 р. у Лондоні, у 1908 р. у Німеччині. До 1910 р. в Європі налічувалось вже більше десяти шкіл [8]. Протягом всього XX ст. в європейських країнах спостерігається, 3 одного боку, посилення ролі держави як суб'єкта соціальної допомоги, формування владної 
інфраструктури соціальної допомоги, а з іншого, зростання участі інститутів громадянського суспільства в різних проектах соціальної допомоги та децентралізація соціальних дій.

Виникнення професії «соціальна робота» в 90-х рр. XX ст. в Україні підтвердило закономірність формування цього професійного виду діяльності в умовах активного розвитку ринкових (капіталістичних) відносин. Цьому процесу передували соціально-політична та соціально-економічна криза в суспільстві, які викликали багато соціальних проблем: різке зниження рівня життя, зростання безробіття, вимушену міграцію населення, зростання рівня злочинності, алкоголізму та інших соціальних патологій. Важливими завданнями професійної діяльності працівника соціальної сфери в цей період стають роз'яснювальна робота 3 окремими громадянами та групами населення, яка спрямована на зниження тривожності; консультаційна робота 3 населенням, зокрема у навчальних закладах, 3 сім'ями; організація соціальної допомоги на дому самотнім непрацездатним громадянам; розробка програм соціального розвитку міст, районів, закладів та участь у реалізації цих програм; розробка концепцій державної політики в сфері соціальної роботи з різними категоріями громадян, перш за все дітьми, молоддю, жінками, пенсіонерами тощо; проведення наукових досліджень, спрямованих на розвиток соціальної сфери; інтеграція різних підходів до розвитку соціальної сфери, які були накопичені в таких сферах професійної діяльності, як педагогіка, медицина, психологія та ін., а також вивчення досвіду зарубіжних країн.

Отже, соціальна робота постійно змінюється в культурно-історичній перспективі. Але безумовним $€$ той факт, що запит на надання соціальної допомоги як професійної послуги зростав у періоди загострення соціальних відносин у суспільстві у відповідь на певні соціальні ризики. На рівні суспільства ці соціальні ризики можна пов'язати з соціальними кризами, які виникали, як правило, внаслідок криз економічних. Соціальна робота стала тим механізмом, який забезпечував можливість необхідного та достатнього життєзабезпечення людей, які за різних причин не могли зробити цього самостійно. Наведений огляд дозволяє також зробити висновок, що історично соціальна робота як професійна діяльність формувалася в період індустріалізму у відповідь на так звані «явні» ризики суспільства, які виникали на локальному або національному рівні, були більш-менш зрозумілими, очевидними, відносно існування яких у суспільстві не виникало сумніву, носії яких також були явними та визначалися як «групи ризику».

На сучасному етапі соціальна робота в різних країнах світу, як і інші види професійної діяльності, знаходиться під суттєвим впливом з боку пандемії COVID-19. Соціологічна рефлексія впливу пандемії COVID-19 на напрями професійної діяльності, в тому числі на соціальну роботу, може здійснюватися на базі різних теоретико-методологічних позицій, але найбільш перспективною уявляється теорія суспільства ризику.

Теорія суспільства ризику отримала розвиток в працях У. Бека, Е. Гідденса та Н. Лумана, в яких ризик розглядається як сутнісна характеристика сучасного суспільства. Найбільш суттєвою характеристикою такого суспільства $є$ інтенсифікація змін і збільшення непередбачуваності суспільного життя, виникнення якісно нового феномена ризику і формування нового ставлення до нього з боку суспільства. В якості основних протиріч такого суспільства виступають два. 3 одного боку, це протиріччя між прагненням до зростання продуктивних сил у зв'язку з бажанням отримувати прибуток і мати певний рівень матеріального добробуту, - i різноманітними небажаними наслідками цього процесу, що несуть загрозу життю і здоров'ю людей. 3 іншого боку, для суспільства ризику характерним $є$ також суперечність між збільшенням невизначеного характеру життєдіяльності, пов'язаного зі збільшенням ризиків, - i нездатністю науки виконувати пояснювальну і прогностичну функції. На відміну від ризиків індустріального суспільства ризики сучасного суспільства мають цілу низку особливостей. Життя в індустріальному суспільстві також було пов'язано з небезпеками і ризиком, проте вони розглядалися як «зовнішні сили» по відношенню до суспільства і людини. Крім того, якщо раніше ризик мав відтінок мужності, пригоди, то в суспільстві ризику він придбав відтінок небезпеки, самознищення. Все більше стає очевидним, що багато ризиків є продуктом тієї ж науково-технічної раціональності, яка в індустріальному суспільстві обіцяла прогрес, розвиток і безпеку. Сучасні ризики носять вже глобальний характер, тому що несуть загрозу всьому живому і не визнають національних кордонів. Вони постійно трансформуються, накопичуються, не мають конкретного джерела. Крім того, вони $є$ «невидимими», тобто не піддаються безпосередньому чуттєвому сприйняттю людей, а представлені в основному у вигляді наукових 
звітів, формул, цифр. Нарешті, їм притаманний «ефект бумеранга», тобто вони рано чи пізно наздоганяють тих, хто їх виробляс. Якісно нові характеристики сучасних ризиків пов'язані також 3 тим, що вони інституціалізовані, тому що існують організації, які приймають ризик в якості провідного принципу власної діяльності. Реакція на ризики з боку суспільства може бути як конструктивною, так і деструктивною. Якщо говорити про конструктивну реакцію, то вона пов'язана з намаганням отримати більше інформації про ризики, взяти участь у соціальних рухах щодо їх врегулювання, зі зміною цінностей тощо. Неконструктивна реакція проявляється в формі їх заперечення, небажання усвідомлювати, зростання фанатичних настроїв, що супроводжуються пошуком «громовідводів для страху». В якості останніх нерідко виступають політики й вчені [1]. Усі ці характеристики можуть бути застосовані й до характеристики ситуації, в якій опинилося людство у зв'язку з пандемією COVID-19 - глобальним найбільш впливовим та «невидимим» ризиком сучасного світу, на який реагують суб'єкти всіх видів професійної діяльності, в тому числі соціальної роботи. Для останньої пандемія COVID-19 стала певним викликом та головним чинником трансформації практик професійної діяльності.

Аналіз наслідків пандемії COVID-19 можна здійснювати 3 використанням різних критеріїв. Так, наприклад, на думку Т. В. Семигіної та Т. М. Скляр можна виокремлювати прямі та непрямі наслідки пандемії для населення в цілому та клієнтів соціальної роботи в різних країнах світу. До прямих наслідків автори відносять втрату роботи, погіршення соціально-економічного статусу, високий ризик зараження в закладах соціального обслуговування, обмеження доступності соціальних послуг тощо. До непрямих - посилення уразливості певних груп, наприклад, людей похилого віку, зростання випадків насильства в родинах, підвищення рівня тривожності та депресії. Крім того, автори надають також огляд практик соціальних працівників в умовах пандемії відповідно до трьох головних функцій соціальної роботи: реагування на індивідуальні та сімейні проблеми, соціальна профілактика та управління [10]. Важливим $\epsilon$ висновок авторів щодо того, що у світі найбільш підготовленими закладами соціальної роботи виявилися заклади тих країні, де була створена належна система реагування на надзвичайні ситуації та здійснювалась підготовка соціальних працівників до дій у таких ситуаціях, до надання екстреної допомоги.

3 нашої точки зору наслідки пандемії COVID-19 необхідно розглядати не тільки узагальнено для соціальної роботи в світі, а й відносно певної країни. Крім того, їх можна розглядати щодо клієнтів соціальної роботи, соціальних працівників, соціальних служб як головного організаційного контексту здійснення соціальної роботи, інших важливих елементів соціальної роботи, а також інституту соціальної роботи загалом. Важливо також здійснювати аналіз позитивних та негативних наслідків.

В Україні протікання пандемії COVID-19 здійснюється в умовах досить складної соціальної ситуації, що суттєво позначається на характері іiі наслідків, у тому числі для соціальної роботи. До особливостей цієї ситуації можна віднести незавершеність суспільної трансформації, низький рівень життя, неефективність діяльності соціальних інститутів, низький рівень довіри до владних інститутів з боку населення тощо.

Всі ці та інші зміни безперечно позначаються й на функціонуванні інституту соціальної роботи в країні загалом, який і так знаходився в процесі становлення. Досить продуктивний погляд на аналіз впливу пандемії COVID-19 на інститут соціальної роботи пропонує концепція еволюційних психологів К. Фінчера та Р. Торнхіллє [12], в основі якої лежить поняття «імунна поведінка». За допомогою цього поняття автори позначають суспільні та індивідуальні дії, які допомагають захиститися від впливу патогенних мікроорганізмів та пандемій. Вчені виходять 3 тези, що власне патогени та пандемії відігравали величезну роль в еволюції людства та вплинули на формування культури, певних моделей поведінки окремих соціальних груп та суспільств в історії. Спираючись на ці ідеї ми можемо припустити, що в умовах відсутності захисних механізмів та суттєвої підтримки з боку суспільства в межах соціальної роботи також можуть формуватися певні моделі «імунної поведінки», спрямовані на захист від пандемії COVID-19 у суб'єктів та клієнтів цієї професійної діяльності, що взагалі може призвести до суттєвої трансформації інституту соціальної роботи в українському суспільстві.

Найбільш докладно наслідки пандемії COVID-19 для професійної соціальної роботи в Україні можна проаналізувати на прикладі діяльності державних соціальних служб. 
Соціальна служба традиційно розглядається в якості провідного суб'єкта професійної соціальної роботи. Як складові системи соціального обслуговування населення, соціальні служби здійснюють соціальну роботу згідно визначеного об'єкта, ступеню спеціалізації, джерела фінансування чи проблеми, на розв'язання якої спрямована їх діяльність. Надаючи соціальні послуги чи здійснюючи допомогу у натуральній і грошовій формах, соціальні служби сприяють подоланню складної життєвої ситуації, в яку потрапили клієнти, й сприяють відновленню процесів їх нормальної життєдіяльності.

Деякі дослідники зазначають, що «особливостями функціонування державних організацій соціальної сфери в Україні на сьогоднішній день є: рівномірне охоплення ними всієї території країни, завдяки їх “вмонтованості” в систему органів влади та, відповідно, централізоване управління системою державних соціальних служб, у більшості випадків обов'язковість звертання самого клієнта до служби, система попереднього відбору клієнтів на основі співвіднесення їх потреб з існуючими соціальними стандартами, чітке визначення кола клієнтів, лояльна поведінка клієнтів щодо служб з одного боку, а 3 іншого - примус щодо клієнтів, поведінка яких трактується як девіантна» [4, с. 204]. Така специфіка обумовлюється провідною роллю держави в управлінні системою соціального обслуговування населення, яка застосовує відповідні організаційно-правові та економічні важелі впливу на організації. Нi держава, ні суспільство не були готові до глобального виклику пандемії, тож механізми регулювання системою соціального обслуговування та окремими соціальними службами доводиться випрацьовувати відповідно до ситуації, що склалась.

Особливості професійної діяльності фахівців організацій, що здійснюють соціальну роботу пов'язані 3 високою емоційністю і стресовістю, адже їм постійно доводиться спілкуватись із непростим контингентом клієнтів. Існує твердження, що працівники установ соціального захисту в своїй діяльності мають практику з так званою "чорною інформацією", яка виходить від проблем їх клієнтів. Держава виявляє себе в якості головного "соціального нападника" i одночасно "соціального захисника". Чим гірше працює цей "нападник", тим більше доводиться долати негативу "рядовому захиснику", що знаходиться на передній лінії соціального фронту, - соціальному працівникові [9]. Очевидно, що в умовах карантину та на грунті власних життєвих проблем, відбулось посилення психологічної напруги, хвилювання за власне життя та добробут близьких людей. Це безумовно суттєво вплинуло на самопочуття клієнтів соціальних служб та відбилось на роботі фахівців.

Аналіз загальних тенденцій змін у суспільстві під впливом пандемії COVID-19 дозволяє обгрунтувати певні наслідки, які можна спостерігати у діяльності соціальних служб в Україні. Доцільно їх розподілити на три категорії: наслідки для організацій системи соціального обслуговування; наслідки для клієнтів соціальних служб та інших установ; наслідки для фахівців цих організацій.

Жорсткий карантин, який довелось пережити країні навесні 2020 року призвів до припинення роботи певної кількості організацій малого бізнесу, скороченню працівників, значних фінансових проблем установ соціального, культурно-рекреаційного, туристичного секторів, збільшенню безробіття i, як наслідок, збідніння значної кількості наших співгромадян. Згідно дослідження інституту демографії ім. Птухи НАН України «у категорію бідних потрапить 45\% населення України за підсумками 2020 року» [2]. Збільшення обсягів фінансування медичної галузі, обумовлені необхідністю боротьби із коронавірусною хворобою та економічні проблеми у державі не могли не відбритись на роботі державних організацій соціальної сфери. Згортання окремих соціальних програм і проектів, скорочення фінансування, звільнення працівників, припинення діяльності організацій, відсутність дієвих засобів правового регулювання питань функціонування за нових умов стали головними негативними наслідками пандемії COVID-19 для організацій системи соціального обслуговування.

Важкі обставини життя клієнтів соціальних служб ускладнились новими актуалізованими ризиками: небезпека зараження COVID-19 і подальшого коштовного лікування, ризики втрати роботи та неможливості задовільнити базові потреби членів сім'ї, загроза важких психологічних переживань та суїцидальних нахилів тощо. Все це посилило уразливість клієнтів i, одночасно, ускладнило роботу із ними фахівців. Особливо негативними виявилися наслідки пандемії для такої групи клієнтів, як люди похилого віку й особи 3 інвалідністю. Ці особи є представниками «групи ризику», тобто відсоток летальних випадків 
цього захворювання серед них є найвищим. У зв’язку з цим, таким клієнтам рекомендовано максимально обмежити спілкування з оточуючими, в тому числі й із соціальними робітниками, які їм надавали різноманітні послуги. Навіть за умови так званого адаптивного карантину в країні заборонено відвідування особами похилого віку установ соціального обслуговування. Отже, ці клієнти не отримують соціальну допомогу належної якості та об'єму. Функція догляду за старшими членами родини та особами з інвалідністю повністю лягла на плечі рідних. Найважче за цих умов одиноким людям, що не здатні до самообслуговування. Таким чином, коронавірус визначив дві групи негативних наслідків для клієнтів соціальних служб і установ: Зниження кількості й (в окремих випадках) якості послуг, що надають фахівці відповідних закладів та значне ускладнення психологічного й соціального самопочуття.

Очевидними $є$ наслідки пандемії для фахівців установ системи соціального обслуговування населення. Як зазначено на Єдиному веб-порталі органів виконавчої влади України «понад 40 тисяч соціальних працівників, незважаючи на посилені карантинні заходи, продовжують працювати у посиленому режимі та щоденно дбають про те, щоб в умовах карантину громадяни похилого віку, особи 3 інвалідністю, сім’ї у складних життєвих обставинах отримували необхідні соціальні послуги» [5]. Професія соціального працівника $\epsilon$ багатофункціональною, контактною, емоційно навантаженою. Щоденне спілкування 3 клієнтами, розв'язування складних завдань, робота із так званою «чорною інформацією», яка часто набуває емоційно-негативного забарвлення, об’єктивно створюють стресові умови та значно збільшують ризики розвитку синдрому емоційного вигорання соціальних працівників. Хвилювання клієнтів стосовно можливості зараження підвищує «градус» емоційної напруги у спілкуванні. Відтак, фахівці перебувають під подвійним тиском страху за життя й здоров'я себе й своїх рідних та відповідальності за клієнтів. Перебування в стані хронічного стресу негативно впливає на здоров'я й самопочуття спеціалістів: загострюються хронічні хвороби, страждає серцево-судинна, нервова, ендокринна та інші функціональні системи. Додатковим чинником ризиків у роботі співробітників соціальних служб та інших установ стала гостра потреба у переході до нових способів роботи, пов'язаних із використанням нових методів і прийомів, комп’ютерних технологій та інформаційних ресурсів. Певна частка фахівців - переважно жінки старшої вікової категорії (у деяких організаціях вони переважають у колективах) - виявились неготові до подібних змін. Це загострило чимало кадрових питань в організаціях.

Але $є$ й певні позитивні наслідки, до яких можна віднести: створення різних каналів інформування населення стосовно актуальної проблеми, зокрема, гарячі лінії, контакт-центр Міністерства охорони здоров'я, тереграм-канали, інформаційні сайти тощо, запровадження системи онлайн реєстрації у різні установи, підписання онлайн-декларації із сімейним лікарем; активно почали розвиватись нові форми дистанційної роботи (наприклад, в умовах карантину Харківський міський центр соціальних служб «Довіра» продовжує надавати послуги дистанційно, якщо ситуація клієнта потребує швидкого реагування з боку працівників центрів соціальних служб, можна скористатися кнопкою «ЕКСТРЕНА СОЦАЛЬНА ДОПОМОГА», яка заходиться на головній сторінці сайту центру соціальних служб а в Немишлянському терцентрі м. Харкова окрім регулярних телефонних консультацій, відбуваються онлайнсемінари 3 фахівцями 3 актуальних питань та профілактики захворюваності). Втім, варто зауважити, що такий формат надання послуг доступний не всім клієнтам соціальних служб. Він фактично диференціює контингент споживачів соціальних послуг за критерієм володіння засобами комунікації (комп'ютер, смартфон, планшет із доступом до мережі Інтернет) та здатністю роботи 3 ними. Тож, аналіз ситуації у цьому аспекті може допомогти зробити висновки щодо можливостей та реальної залученості клієнтів соціальних служб до онлайн роботи. У певному сенсі позитивним можна вважати й кадрове «оновлення» соціальних служб, адже стали затребуваними фахівці, що мають нові уміння й навички, пов'язані із роботою 3 інформаційними платформами та інтерактивними програмами. Це стимулює спеціалістів до навчання, підвищення кваліфікації, освоєння інноваційних технологій і методів роботи.

Висновки. Таким чином, історично соціальна робота як професійна діяльність формувалася в період індустріалізму у відповідь на так звані «явні» ризики суспільства. В сучасних умовах соціальна робота знаходиться під впливом пандемії COVID-19, яка є найбільш впливовим глобальним «неочевидним» ризиком, що суттєво трансформує цей напрям професійної діяльності. 
Наслідки пандемії COVID-19 можна розглядати не тільки узагальнено для соціальної роботи в світі, а й відносно певної країни. Крім того, їх можна розглядати щодо клієнтів соціальної роботи, соціальних працівників, соціальних служб як головного організаційного контексту здійснення соціальної роботи, а також інституту соціальної роботи в цілому.

Головними наслідками пандемії COVID-19 для діяльності державних соціальних служб як одного з провідних суб'єктів соціальної роботи в Україні стали згортання окремих соціальних програм і проектів, скорочення фінансування, кадрові зміни, припинення діяльності організацій, відсутність дієвих засобів правового регулювання питань функціонування за нових умов, перехід до дистанційних форм надання послуг та онлайн роботи. Наслідками для клієнтів та фахівців соціальних служб стали зниження кількості й (в окремих випадках) якості послуг, що надають фахівці відповідних закладів та значне ускладнення психологічного й соціального самопочуття, ризики захворювання й емоційного вигорання останніх, необхідність освоєння комп'ютерних програм та нових методів роботи. Зазначені наслідки носять як позитивний, так і негативний характер для діяльності організацій, клієнтів, фахівців, системи професійної соціальної роботи в цілому.

У статті використані також положення теорії імунної поведінки та зроблено висновок, що пандемія $\epsilon$ важливим чинником формування захисних моделей «імунної поведінки»у клієнтів соціальної роботи та соціальних працівників та може призвести до суттєвої трансформації інституту соціальної роботи в українському суспільстві.

Насамкінець слід зазначити, що особливості професійної діяльності соціальних працівників, практики подолання кризових ситуацій клієнтів, особливості трансформації інститут соціальної роботи в Україні під впливом COVID-19 безперечно потребують подальшого теоретичного та емпіричного дослідження.

\section{REFERENCES}

1. Bek U. Obshhestvo riska. Na puti k drugomu modernu / Per. s nem. V. Sedel'nika i N. Fedorovoj; Posleslov. A. Filippova. Moskva : Progress-Tradicija, 2000. 384 s.

2. Bidnist' v Ukraïni torknet'sja $45 \%$ naselennja. Ce znachno vishhe dokrizovih prognoziv URL: https://uanews.liga.net/economics/news/bidnist-v-ukraini-torknetsya-45-naselennya-tse-znachno-vische-dokrizovihprognoziv (data zvernennja: 18.11.2020).

3. Glazunov, S.V. Narisi z istoriï social'noï roboti: navch. vid. / S.V.Glazunov. D.: RVV DNU, 2015. 116 c.

4. Derzhavni ta nederzhavni organizaciï social'noï sferi v Ukraïni: osoblivosti vzaєmodiï ta perspektivi rozvitku / V. I. Kogut, S. K. Andrejchuk. Efektivnist' derzhavnogo upravlinnja. 2016. Vip. 3. S. 201-207.

5. Edinij veb-portal organiv vikonavchoï vladi Ukraïni. URL: https://www.kmu.gov.ua/news/v-umovahkarantinu-socialni-pracivniki-pracyuyut-u-posilenomu-rezhimi (data zvernennja: 19.11.2020).

6. Zhmajlo A.I. Social'nyj risk kak pokazatel' societal'noj transformacii sovremennogo obshhestva. Vestnik JuUrGU . Serija «Social'no-gumanitarnye nauki». Vyp. 11. 2008. № 21 (121). S. 83 - 88. URL: https://cyberleninka.ru/article/n/sotsialnyy-risk-kak-pokazatel-sotsietalnoy-transformatsii-sovremennogoobschestva (data zvernennja: 15.11 .2020 )

7. Kelas'ev V.N. Social'naja rabota: sovremennye vyzovy i prognoziruemye reshenija. Vestnik SanktPeterburgskogo universiteta. Serija: Sociologija. Vyp. 3. 2012. S. 135 - 144. URL: https://cyberleninka.ru/article/n/sotsialnaya-rabota-sovremennye-vyzovy-i-prognoziruemye-resheniya (data zvernennja: 15.11.2020)

8. Krasovskaja N.N. Vozniknovenie social'noj raboty i specifika ee rannih form i metodov. Filosofija i social'nye nauki. 2014. №4. S. 56 - 61. URL: https://core.ac.uk/download/pdf/38538864.pdf (data zvernennja: 15.11 .2020 )

9. Organizacija, upravlenie i administrirovanie v social'noj rabote : uchebnik dlja bakalavrov / E. I. Holostova, E. I. Komarov, O. G. Prohorova ; otvetstvennyj redaktor E. I. Holostova, E. I. Komarov, O. G. Prohorova. Moskva : Izdatel'stvo Jurajt, 2016. 425 s. URL: https://urait.ru/bcode/388314 (data zvernennja: 18.11.2020).

10. Semigina T. V., Skljar T. M. Vidpovid' social'noï roboti na vikliki pandemiï COVID-19. Logos. Paradigmatic view on the concept of world science. Volume 1. August 21. 2020. P.154-156.

11. Shanin T. Social'naja rabota kak kul'turnyj fenomen sovremennosti (Novaja professija i akademicheskaja disciplina v kontekste social'noj teorii i politicheskoj praktiki nashego dnja). Voprosy filosofii. 1997. № 11. S. 55-72.

12. Shah S. Pandemija: Vsemirnaja istorija smertel'nih virusov / Per.s angl. Moskva : Al'pina non-fikshn, 2017. 757 s. 